\title{
MACROPRUDENTIAL AND MONETARY POLICY TRANSMISSION ISSUES
}

\author{
NINO ZHORZHIKASHVILI \\ Doctoral student of Macroeconomics, \\ Ivane Javakhishvili Tbilisi State University \\ nino.zhorzhikashvili1993@gmail.com
}

Abstract. Before the global financial crisis, it was widely believed in academic circles, that there was a conflict (inflation / financial stability) between monetary policy and prudential policy, which justified the separation of monetary and prudential functions. Due to this approach, a significant trend of segregation of functions was observed in some countries. Weaknesses of this approach became apparent after the crisis, thus countries actively began to adopt macroprudential policy integrated with monetary policy, which ultimately increases the effectiveness of both policies in terms of achieving the stability of country's economic, banking and financial sectors.

\section{KEYWORDS: MACROPRUDENTIAL POLICY, MONETARY POLICY, TRANSMISSION MECHANISM.}

For citation: Zhorzhikashvili, N., (2021). Macroprudential and Monetary Policy Transmission Issues. Globalization and Business, №11, 74-79. https://doi.org/10.35945/gb.2021.11.009

The effective implementation of the macroprudential approach depends on the supervision and coordinated action of the central bank. Central banks are naturally involved in macroprudential policy, thus monetary policy is increasingly using unconventional regulatory methods and tools as macroprudential policy instruments.

Some countries (Belgium, Ireland, England) have completely returned to the central bank the prerogative of supervising of the financial sector in the aftermath of the financial crisis. Although the supervisory agency operates separately in the following countries: Denmark, Austria, Luxembourg, Sweden, France, Germany and Finland, integration with central banks has increased since the global crisis. In addition, France, Germany and Austria are using joint supervision. In addition, the European Central Bank, which pursued only monetary policy before the 2008 global crisis, was tasked in 2012 with supervising large banks in the eurozone (European Commission, 2012).

Monetary policy should be largely responsible for regulating the business cycle, which means stabilizing inflation rates and interest rates by using inflation "targeting". However, it should be noted that no central bank can fully control the financial markets. But monetary policy has an excellent instrument in the form of macroprudential policy, that can take responsibility for the stability of the financial system and the financial cycle. The impact of classical monetary policy channels on the economy is limited because, on the one hand, security markets are underdeveloped in some countries, and, on the other hand, interest rate dynamics are more dependent on structural factors than on monetary conditions.
Moreover, it should be noted that monetary policy can even contribute to the accumulation of risks in the financial sector (Cavallari, 2016). In particular, when the central bank aims to stimulate consumer spending by lowering interest rates, this may significantly increase security prices and create a breeding ground for a "speculative soap bubble", that threatens financial stability. On the other hand, pursuing a restrictive monetary policy raises interest rates, which reduces aggregate demand in the economy, and may lead to a slowdown in the long-term growth rate of the economy. Thus, monetary policy faces challenges and it is clear, that achieving financial stability in isolation is impossible. Therefore, no country today considers monetary and macroprudential policies in isolation, on the contrary, the success of the coordinated use of their instruments can be seen in practice of many countries.

As mentioned, price stability alone is not a sufficient condition for financial stability. An example of this is the stable pre-crisis price level in the euro area, accompanied by credit cycle fluctuations and instability (Deutshe Bundesbank, 2015). During this period, the prices of securities and credit volumes increased rapidly in the euro area (graph 1). As can be seen from the graph, against the background of price stability, there was an unstable situation in the financial sector, which the monetary policy could not foresee and respond to. And because credit cycles are more volatile than business cycles, it is essential to actively apply macroprudential policy and coordinate it with monetary policy.

Based on the above described situation, the issue of integration of macroprudential and monetary policies and the 
Graph. 1. Credit and business cycles in the euro area

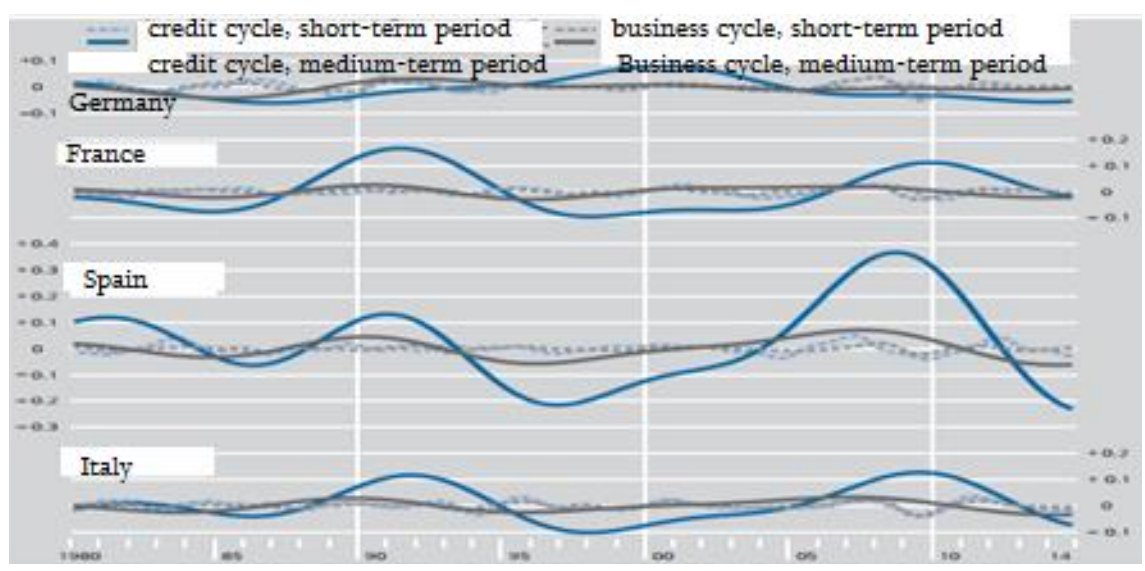

Source: ECB ("ECB Balance Sheet Items", loans of domestic MFIs to the non-financial private sector in the euro area, outstanding loan amounts at the end of the quarter) and OECD ("Main Economic Indicators", real GDP and the consumer price index to determine real outstanding loan amounts).

need for close coordination arises. Both policies work to ensure financial stability, albeit with different instruments and channels, although their ultimate goal is one - to promote sustainable country development and long-term economic growth (see table 1 and table 2). Monetary policy contributes to price stability and output levels in the economy, while macroprudential policy focuses on identifying and eliminating systemic risks. As a result of the integration of these policies, the economic system becomes more resilient and flexible to shocks and allows the defects of both policies to be overcomed. Macroprudential policy interventions with capital counter-cyclical buffer and other instruments aims to neutralize pro-cyclicality in financial sector, which largely determine the effectiveness of monetary policy (Komarkova, 2011). The continuous development of innovations and technologies in the financial sector requires closer coordination and the implementation of well-organized policies based on the existing reality.

Table 1. The relationship and objectives of macroprudential and monetary policy

\begin{tabular}{|l|l|l|l|l|}
\hline & Policy & Goal & & Ultimate goal \\
\hline $\begin{array}{l}\text { (Shonetary } \\
\text { Macroprudential } \\
\text { (CCyB, LTV, DTI...) }\end{array}$ & Price Stability & & $\begin{array}{l}\text { Stable and non-inflationary } \\
\text { economic growth }\end{array}$ \\
\hline
\end{tabular}

Source: Shhoenmaker D., Wierts P.,, "Macroprudential Supervision: from theory to Policy", 2015:3

Table 2. Characteristics of monetary and macroprudential policies

\begin{tabular}{|l|l|l|}
\hline Target, area of action & Monetary policy & Macroprudential policy \\
\hline ultimate goal & $\begin{array}{l}\text {-Price stability (low inflation rate) } \\
\text {-Reduction of fluctuations in economic } \\
\text { activity }\end{array}$ & $\begin{array}{l}\text {-Identification of financial risk } \\
\text {-Reduction of costs caused by systemic } \\
\text { risks to a minimum }\end{array}$ \\
\hline Indicators of risk and its intensity & $\begin{array}{l}\text {-Deviation of the inflation rate from } \\
\text { the target } \\
\text { - Variability of economic activity, profit }\end{array}$ & $\begin{array}{l}\text {-Excessive debt } \\
\text { - Variability of stock prices } \\
\text {-Excess liquidity above the allowable } \\
\text { mark } \\
\text {-Confition of the financial sector } \\
\text {-Increase the loan volume }\end{array}$ \\
& & $\begin{array}{l}\text {-Strict tightening of banking- } \\
\text { supervisory regulations } \\
\text {-Macroprudential policy instruments } \\
\text { Instruments }\end{array}$ \\
& $\begin{array}{l}\text { - Monetary policy rate } \\
\text {-Currency interventions } \\
\text { loans and high risk instruments }\end{array}$ \\
\hline
\end{tabular}

Source: Cavallari M., “Monetary Policy and Macro Prudential Regulation: Whither Emerging Markets”, $2013: 15$. 
To illustrate the effectiveness of the joint application of macroprudential and monetary policies, the authors (Eugenio, Claessens, 2016) proposed a model:

$$
\begin{aligned}
& \Delta \text { Log } \text { Credit }_{b f t}=\delta_{f}+\sum_{j=1}^{4} \beta_{j} \Delta \text { Macropru }_{t-j}+\sum_{j=1}^{4} \delta_{j} \Delta \mathrm{r}_{t-j}+ \\
& \sum_{j=1}^{4} \gamma_{j} \Delta \text { Macropru }_{t-j} * \Delta \mathrm{r}_{t-j}+\text { controls }_{b f t}+\text { quarter }_{t}+\varepsilon_{b f t}
\end{aligned}
$$

The model includes the real growth rate $(\Delta \mathrm{rt})$ of monetary policy as a variable, as for, $\sum_{j=1}^{4} \mathrm{yj}$,

it determines the direction of the interaction between macroprudential and monetary policy. We can define the first-order derivatives of these policies:

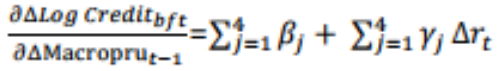

$$
\begin{aligned}
& \frac{\partial \Delta \text { Log Credit }_{\text {bft }}}{\partial \Delta r_{t}}=\sum_{j=1}^{4} \delta_{j}+\sum_{j=1}^{4} \gamma_{j} \Delta \text { Macropru }_{t-1}
\end{aligned}
$$

Since the coefficients, $\sum_{j=1}^{4} \beta j$ and $\sum_{j=1}^{4} \delta j$

are most likely negative (tightening monetary and macroprudential policies reduces the volume of loans issued), the impact of one policy change on another will depend on the sign of the second order derivative of the series

$$
\frac{62 \Delta \log \text { Credit bft }}{6 \Delta \text { Macropru } t-1 \Delta \mathrm{rt}}=\sum_{j=1}^{4} \mathrm{Yj} \text {. If } \sum_{\mathrm{j}=1}^{4} \mathrm{Yj}<0,
$$

then each policy will reinforce each other and the combined effect will be greater on the economy. Conversely, if tightening of macroprudential policy reduces the effectiveness of tightening monetary policy or vice versa, then

$$
\sum_{j=1}^{4} Y j>0 .
$$

Therefore, we can conclude that if these policies move in one direction, more favorable conditions are created for financial and economic stability.

$$
\begin{aligned}
& \sum_{j=1}^{4} Y_{j} \Delta \text { Macropru } t-j * \Delta r t-j \text { in formule } \sum_{j=1}^{4} Y j \\
& \text { in formule } \sum_{j=1}^{4} y j,
\end{aligned}
$$

negative value implies, that tightening macroprudentia and monetary policies reduces the volume of loans $(\Delta \mathrm{log}$ -

Table 3. Impact of macroprudential and monetary policy shocks on various indicators (Forecast error variance decomposition, monetary and macroprudential shocks)

\begin{tabular}{|ll|l|l|l|l|}
\hline Period & & 1 year & 2 year & 3 year & 4 year \\
\hline CPI & PP & 1.9 & 7.2 & 10.3 & 12.3 \\
& R & 1.2 & 6.4 & 6.5 & 6.0 \\
\hline CRD & PP & 0.4 & 1.6 & 3.6 & 5.9 \\
& R & 0.9 & 3.0 & 3.8 & 4.0 \\
\hline RGDP & PP & 3.7 & 6.6 & 8.2 & 9.3 \\
& R & 0.6 & 2.3 & 2.7 & 2.9 \\
\hline
\end{tabular}

Source: Kim S., "Effects of monetary and macroprudential policies - evidence from inflation targeting economies in the Asia-Pacific region", 2017:16
Creditbft) and this effect is greater, when both policies (macroprudential- $\Delta$ Macropru $\mathrm{t}-\mathrm{j}$ and monenary $\Delta \mathrm{r} \mathrm{t}-\mathrm{j}$ ) operate simultaneously and in one direction rather than in a separate case.

Therefore, we can conclude that:

1) Macroprudential policy is very effective in regulating the credit cycle,

2) Macroprudential instruments have the greater effect on the credit cycle, when the the integration with monetary policy is closer.

A study by Kim (2017) for countries in the Asia-Pacific region revealed, that macroprudential policy plays a more important role in explaining price fluctuations than monetary policy. In particular, for the 4-year time horizon, macroprudential policy shocks accounted for $12.3 \%$ of price fluctuations, and in the case of monetary policy shocks, $6 \%$ of price fluctuations (Kim, 2017: 17-18). At the same time, the impact of macroprudential policy on real GDP is greater for the long run, than monetary policy impact, in particular, macroprudential policies describes $9.2 \%$ of the GDP fluctuation, while monetary policy accounts only $2.9 \%$. Therefore, macroprudential policy has a great impact on the volume of GDP, its growth rate, aggregate demand and the real sector of the economy in general.

In addition, a study conducted by the IMF on the US banking and financial sector for 1999-2015, shows that the impact of macroprudential policy instruments on various economic indicators is more immediate, although unlike monetary policy, its effect is shorter (see graph 2 and graph 3 ).

Monetary policy shock reduces bank lending by $0.5 \%$ after 7 quarters and by $1 \%$ after 12 quarters. The same shock reduces real estate prices by $4 \%$ after 7 quarters and by $10 \%$ after 12 quarters.

In addition, it should be noted, that in the case of tightening monetary and macroprudential policies, their impact on bank loans is greater than in the case of policy easing. To illustrate this, consider graph 3, which shows the impact of tightening / easing policies on bank lending.

The graph shows that in the conditions of a tight regime of both monetary and macroprudential policies, bank loans decrease more than in the case of a pursuing easing policy. Therefore, restrictive policies have a greater impact on the percentage change in loans than mitigation policy, which must be taken into account by policy makers to achieve stability in the real and financial sectors of the economy.

To sum up, it can be concluded that the monetary policy response is delayed in time, its effects require a relatively large period of time to achieve the desired effect, so it is necessary to actively use macroprudential policy that can stabilize the financial sector in the short term. Therefore, great importance is attracted to the integration of these policies and their simultaneous use to prevent macroeconomic shocks.

\section{COMMON TRANSMISSION CHANNELS OF MACROPRUDENTIAL AND MONETARY POLICIES}

The interaction between macroprudential and monetary policies is quite strong, which is due to the fact that they have common transmission channels (Trivedi, 2018). Decisions 
Graph 2. Tightening of monetary policy and its impact on bank lending and real estate prices in the US (\% change)

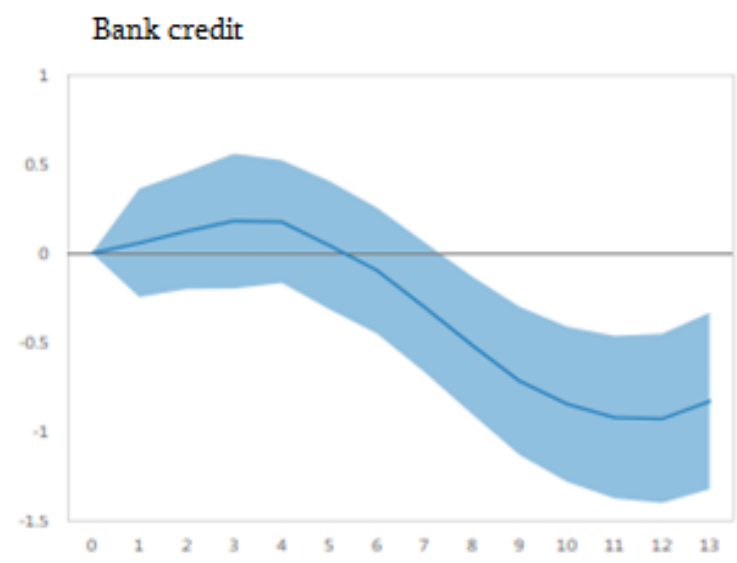

Real estate prices

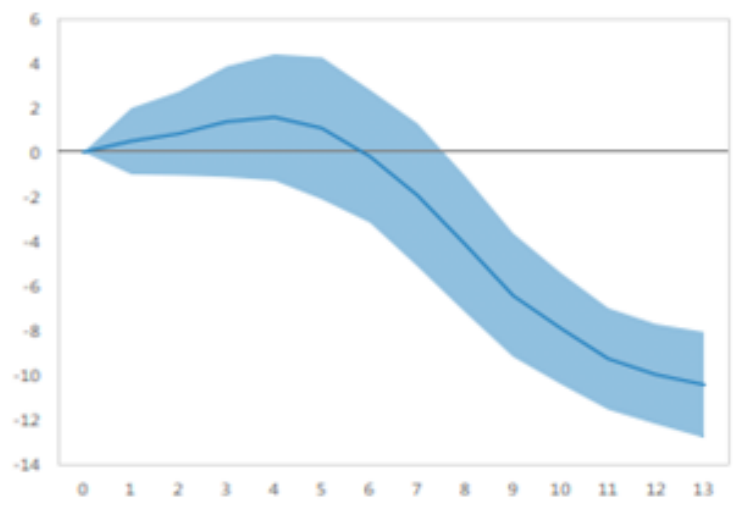

Time lag

Source: IMF, "Effects of Monetary and Macroprudential Policies on Financial Conditions: Evidence from the United States", 2015: 5-7

Graph 3. Impact of monetary and macroprudential policies on bank lending in the US (\%)

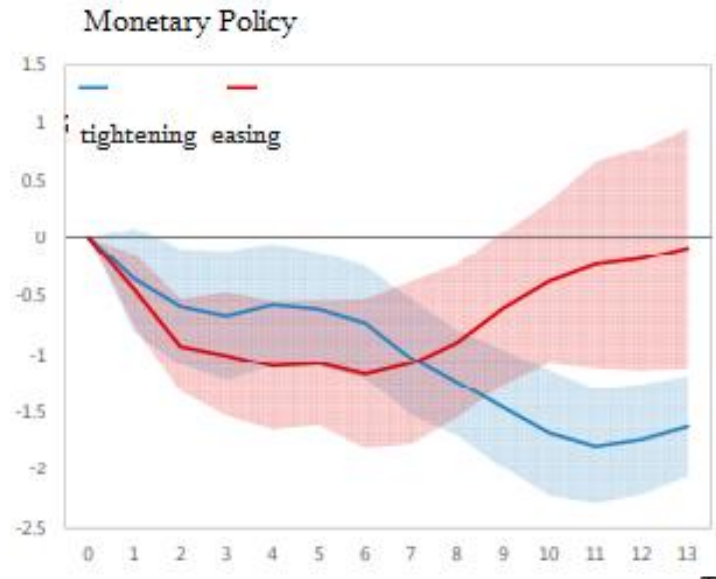

Macroprudential Policy

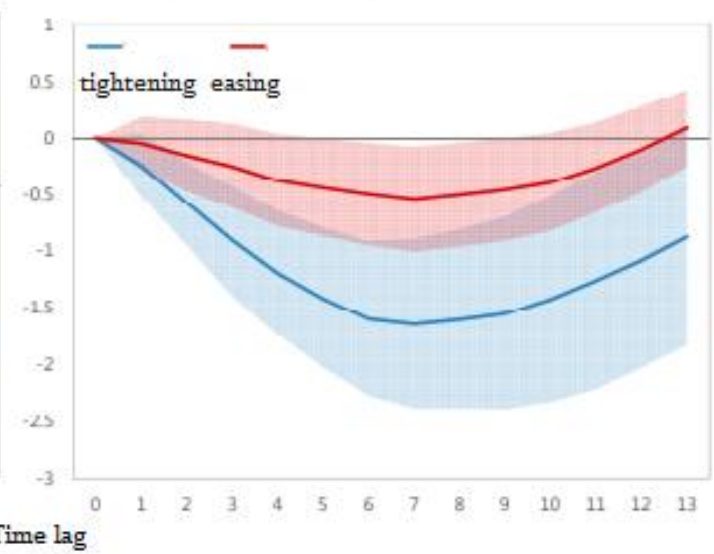

Source: IMF,"Effects of Monetary and Macroprudential Policies on Financial Conditions: Evidence from the United States", 2015:13-15

made in one policy have a great impact on the effectiveness of the other policy and its consequences. Such as equity countercyclical buffer, liquidity repayment ratio, etc. offers new ways to regulate credit and financial cycles.

- Broad credit channel -is one of the most common transmission channels used by both policies. Bank lending and its management are used successfully both in monetary policy and macroprudential policy. When the central bank implements a restrictive monetary policy, thereby reducing the amount of money in circulation, in turn commercial banks issue fewer loans to firms and households. As a result, the volume of loans is limited, which increases the interest rate and increases the risk of "moral hazard" by companies, because they are interested in investing in more risky projects to get high returns. Therefore, an increase in interest rates is a signal to banks, that risks are accumulating in the financial sector and consequently lending conditions are tightening. Under such conditions, macroprudential policy instruments such as the minimum reserve requirements, adopted by in Basel III, play a crucial role in regulating the financial cycle.

- Interest rate channel - Monetary policy aimed at lowering interest rates may have a negative impact on the condition of financial institutions, as lower interest rates mean lower returns. The 2008 crisis showed that due to reduced yields, financial institutions and private commercial banks began to use new financial instruments, which were seemingly safe, but became a major threat during the crisis and caused financial instability.

However, it should be noted that the effectiveness of monetary policy at the national level is becoming increasingly weak as a result of global integration of financial markets. As Chairman of the US Federal Reserve, Ben Bernanke ${ }^{1}$ says, the increase in global savings has led to a sharp decline in

${ }^{1}$ American Economist, chairman of United States Federal Reserve System, 2006-2014 
Graph 4. Expansive monetary policy and level of risks, US, 1997-2008

\section{Expansive monetary policy and risk level}

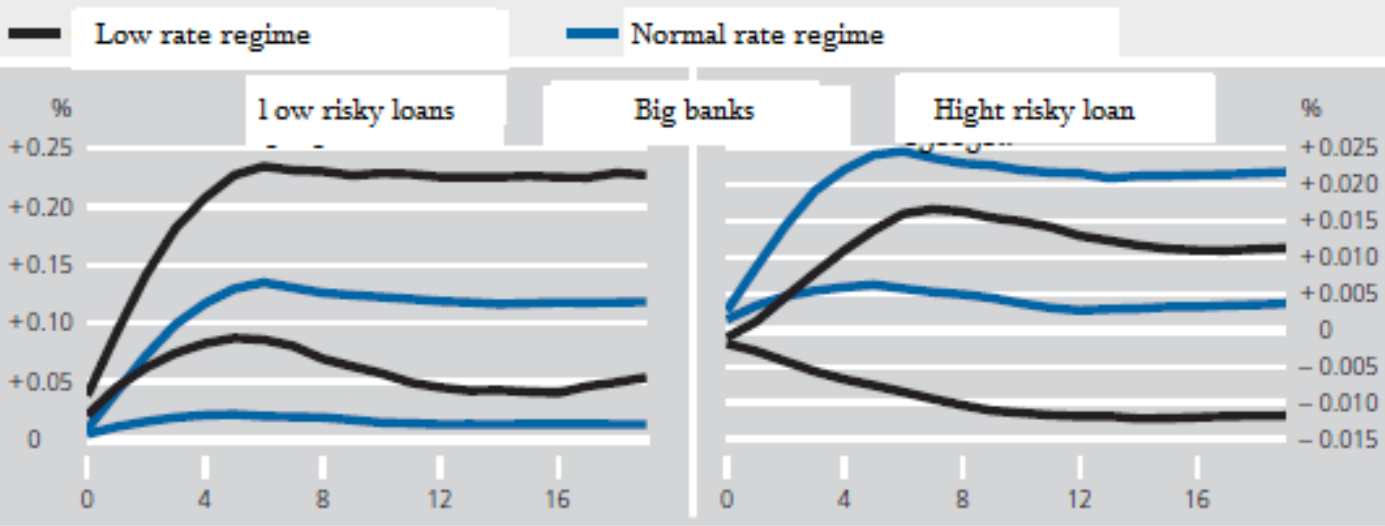

Source: Deutsche Bundesbank, "Financial Stability Review", 2012:5

long-term interest rates in developed countries, which in turn has weakened its link to short-term interest rates. Due to this fact, the monetary policy impact on the short-term interest rate is reduced significantly, which also showed weakened impact the long-term interest rate. This fact indicates the weakening role of monetary policy in ensuring financial stability (Bernanke, 2015).

Empirical surveys of the United States (Jiménez, Ongena, Peydró, Saurina, 2014) were obtained from quarterly reports of the Federal Reserve System. The purpose of the study was to analyze the impact of monetary policy on the volume and dynamics of borrowing. The study analyzed the volume of loans in dollars at the level of the minimum interest rate and the normal level in 1997-2008 (Deutsche Bundesbank, 2015). The graph clearly shows the negative relationship between the policy rate and the degree of risk (Graph 4). As the figure shows, the monetary policy pursued by the central bank can have a major impact on the financial system, in particular even stimulating risky transactions by financial institutions.

- Exchange rate channel - In the open economy, the central bank can influence exchange rate and capital flows through monetary policy. Large inflows of capital can put the country at risk due to excessive credit and liquidity. This is easier to understand by looking at a small open economy like Ireland. The country's central bank has tightened monetary policy to curb inflation. As a result, interest rate hikes have made the country more attractive in terms of investment, which has led to a large capital flows into the country. Many Eastern European countries faced this dilemma before the global crisis (Graph. 5).

- Bank Capital Channel- This refers to the observance of mandatory capital norms and requirements by banks. One of the such instruments is the requirement to maintain capital adequacy, forcing banks to increase the amount of their assets in excess of the amount of loans issued. However, there are other requirements such as liquidity, solvency, etc. Depositors place cash in the bank in the expectation, that they will receive more interest on each invested item tomorrow, however, various risks (liquidity, market, credit) may become the cause of the bank's insolvency. As depositor assets decrease due to deteriorating economic conditions, they require the bank to raise interest rates, which in turn leads to reduced economic activity (Cozz, Darracq, Karadi, 2020).

Macroprudential policy is particularly important in this

Graph 5. The relationship between inflation rates and real estate prices
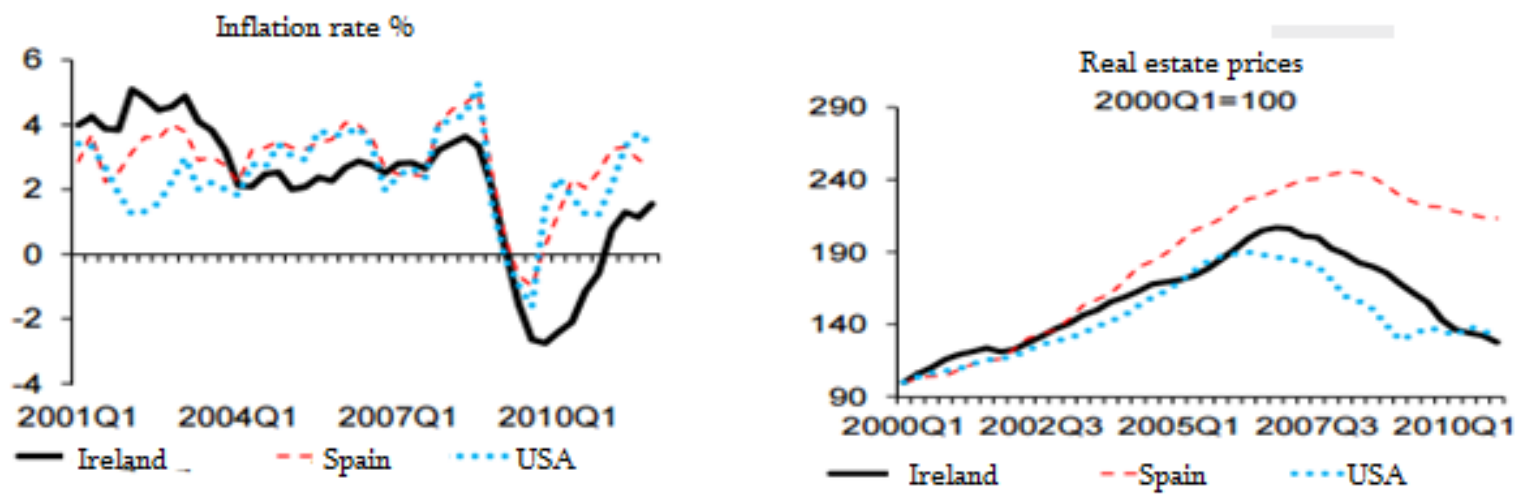

Source: Blanchard O., Vinals J.,World Economic Outlook and Haver Analytics,,"The Interaction of Monetary and Macroprudencial Policy", 2013:23. 
regard, as it provides for mandatory minimum capital requirements for the bank, which are defined on the basis of the principles and regulations of Basel III, and allow the bank to assess its balance sheet and creditworthiness.

\section{CONCLUSION}

The 2008 global financial crisis once again raised the issue of more active application of macroprudential policy, as it became clear that monetary policy and its regulations alone could not ensure stability in the banking and financial sector. The aim of macroprudential policy is to increase the degree of resilience of the financial system to endogenous shocks, to limit the emergence of financial imbalances and to minimize the economic costs caused by imbalances. Therefore, coordination and close link with monetary policy is a necessary and inevitable condition to achieve this goal, as the effective implementation of the macroprudential approach depends on the coordinated action of the supervisory body and the central banks. Central banks are naturally involved in the macroprudential policy process. Finally, it should be noted, that the example of many countries has practically proven the effectiveness of the integration of the above policies and their simultaneous application in preventing macroeconomic shocks and ensuring the stability of the banking and financial sector.

\section{REFERENCES:}

Bernanke, B., (2015). Federal Reserve Policy in an International Context:23-24, 37.

Blanchard, O., Vinals, J., (2013). World Economic Outlook and Haver Analytics, he Interaction of Monetary and Macroprudencial Policy:23.

Canutto, O., \& Cavallari, M., (2013). Monetary Policy and Macro Prudential Regulation: Whither Emerging Markets:15.

Cerutti, E., Claessens S., \& Laeven L., (2016). The use and effectiveness of macroprudential policy:5-6.

Cozzi, D., Pariès, M., \& Karadi P., (2020). Macroprudential policy measures: macroeconomic impact and interaction with monetary policy:20-21

Deutsche Bundesbank. (2015). The importance of macroprudential policy for monetary policy, 51

IMF. (2015). Effects of Monetary and Macroprudential Policies on Financial Conditions: Evidence from the United States, 5-7, 13-15

Kim, S., \& Mehrotra, A., (2017). Effects of Monetary and Macroprudential Policies - Evidence from Inflation TargetingEconomies in the Asia-Pacific Region, 16-20

Komarkova, Z., (2011). Financial stability, systemic risk and macroprudential policy, 33

National Bank of Georgia. (2019). Macroprudential Policy Strategy for Georgia, 5-10

Nelson, W.,\& Perli R., (2015). Selected indicators of financial stability, 8

Shhoenmaker, D., \& Wierts, P., (2015). Macroprudential Supervision: from theory to Policy:3-5

Trivedi, K., (2018). An empirical study of the circumstance sunder which macroprudential policy can be compounding, neutral or conflicting to the conduct of monetary policy:8-11 